\title{
The role of contracts in achieving effective governance of intermodal terminals
}

\section{Rickard Bergqvist*}

Department of Business Administration, School of Business, Economics and Law, Gothenburg University, P.O. Box 610, SE 40530 Gothenburg, Sweden

E-mail: rickard.bergqvist@handels.gu.se

*Corresponding author

\section{Jason Monios}

Transport Research Institute, Edinburgh Napier University, Merchiston Campus, EH10 5DT Edinburgh, UK

E-mail: j.monios@napier.ac.uk

\begin{abstract}
Public sector actors often provide financial or planning support to intermodal terminal developments with the aim of achieving societal benefits through modal shift from road haulage to rail transport. Once operational, such terminals exhibit a variety of governance models with varying levels of power and responsibility shared between public and private actors. This paper reviews a selection of contracts between rail infrastructure owners, terminal owners, terminal operators and rail operators in order to determine the incentives, commitments and risks involved in specifying such responsibilities between actors. The two markets analysed are Sweden and the UK, with similar histories of liberalisation of rail operations. In the Swedish context, terminal infrastructure owners, usually public actors, want to act as landlords but continuously find themselves involved in daily operational and commercial situations. In the UK, long leases on token rents mean that few commitments or investments are required by private operators as long as they remain in use and allow open access. Policy implications are discussed and recommendations made for future research.
\end{abstract}

Keywords: governance; intermodal terminals; regulation; policy; rail; freight; public-private partnerships; risk; lease.

Reference to this paper should be made as follows: Bergqvist, R. and Monios, J. (2014) 'The role of contracts in achieving effective governance of intermodal terminals', World Review of Intermodal Transportation Research, Vol. 5, No. 1, pp.18-38.

Biographical notes: Rickard Bergqvist is an Associate Professor in Logistics and Transport Economics and Head of the Graduate School at the School of Business, Economics and Law, Gothenburg University. His key research areas are maritime logistics, regional logistics, intermodal transportation, dry ports and public-private collaboration. His major works include over 20 refereed 
journal articles, conference papers and book chapters related to intermodal transport, dry ports, economic modelling, maritime economics and public-private collaboration.

Jason Monios is a Senior Research Fellow at the Transport Research Institute, Edinburgh Napier University, UK where he leads research and consultancy projects in the Maritime Transport and Logistics Research Group. His primary research area is intermodal freight transport, with a specific interest in the relations between ports and inland terminals in managing hinterland access. He has published widely on intermodal terminals, dry ports, regional port development and the institutional challenges to successful intermodal transport and logistics. He is a Fellow of the Royal Geographical Society and a member of the International Association of Maritime Economists.

\section{Introduction}

A significant amount of research on intermodal transport has focused on the development of terminals, particularly the role of the public sector in supporting such facilities with financial or planning support (e.g., Bergqvist, 2013; Caris et al., 2008; Flämig and Hesse, 2011; Liedtke and Carillo Murillo, 2012; Monios and Wilmsmeier, 2012; Ng and Gujar, 2009; Roso, 2008). This public sector support is based on expected benefits such as emissions and congestion reduction due to modal shift to rail or increased competiveness arising from improved access to major trade links. These expectations are based on ideal scenarios of significant modal shift, but such scenarios are only likely if the terminals can offer a high quality handling service at low prices to the rail service operators, who in turn can then offer regular reliable services to shippers and forwarders at prices competitive with road haulage. The relationship between public sector planners and funders and private sector rail operators is thus of the utmost importance in establishing economically competitive intermodal terminals.

Such analysis of the role of the public sector in terminal development has become a topic of increasing pertinence due to the liberalisation of rail operations in Europe with the result that both public and private actors are involved in developing, maintaining and using rail infrastructure. Hesse (2008, p.46) observed that the consequence of this situation is that "policy goals become more difficult to achieve: competitive dynamics between firms and - particularly - between municipalities do not allow for setting standards, demanding for commitments, etc. The more speculative the nature of development, the more contingent planning will be”.

This contingent nature of modern planning for intermodal transport means that public actors find it difficult to tie funding support for intermodal terminal development to conditions for the operational model of the terminal. This situation raises the risk that the terminal may not be operated on a viable economic model capable of supporting a rail service of sufficient quality to be attractive to shippers and forwarders and thus achieve the desired modal shift. The result can be that the terminal ceases operation or requires ongoing public subsidy. Research is, therefore, required into the link between the initial funding (both public and private) and the business model of the terminal. The business model will have as much determining influence on the success of the terminal as 
transport cost analysis of what may be an ideal scenario (e.g., regular full trains in both directions), yet it is the latter that usually forms the basis of public sector funding decisions. Therefore, this paper will analyse the business model as it is observed in the contracts between key actors in the rail industry.

The empirical analysis in this paper is based on a selection of contracts between the infrastructure (network) owner, the infrastructure (terminal) owner, the terminal operator and the rail operator, analysed within the context of the rail system in each country. The issues raised by this analysis are given additional context through interviews with some of the contracted parties. The two countries analysed are Sweden and the UK, according to the rationale that these are two of the earliest countries in Europe to liberalise their rail freight networks and vertically separate infrastructure and services ${ }^{1}$. The methodology is necessarily exploratory due to the small sample of commercially sensitive data; nevertheless, it is the process of specifying responsibilities in contracts that is being observed rather than establishing the frequency of such contract types. The goal is therefore to identify and classify incentives, responsibilities, commitments and risks involved in such contract negotiations and specifications, which can then be used to develop a template applicable in other national contexts to compare how the same contractual features are managed in other cases.

The theoretical background is drawn from port governance where a large body of work has analysed how public and private aims are achieved through various governance models. The landlord model has proved the most popular because it retains a mechanism for public sector aims to be achieved while also increasing efficiency and lowering prices by allowing experienced private sector operators to compete for the market. While analysis of the best governance models has been a rich seam of research in the port sector, this topic has received little attention in the intermodal literature. This oversight is surprising since a large quantity of resources has been spent developing terminals with an apparent assumption that the development process is the difficult part and that once a site is built it can be handed over to the private sector for efficient and economically competitive operation. The large number of underutilised terminals in Europe suggest that this is not the case; research is, therefore, needed to address governance models at intermodal terminals to understand the different motivations of each actor and how they attempt to achieve them through the agreements they make with each other in terms of contract lengths, service requirements, maintenance, price, retention of infrastructure investments and so on.

Following this introduction, the paper reviews the literature on port governance and then applies these findings to the key issues relevant to intermodal terminal development and operation. The context of the rail sector is then explained in order to identify the contractual relationships to be examined through empirical analysis. Section 4 presents the empirical content which is then analysed in the following section. Section 6 concludes with the policy implications of the current situation and recommendations for future research. 


\section{Theoretical background for governance analysis}

\subsection{Introduction to governance}

Two useful theoretical approaches to logistics management are transaction cost economics (TCE) and resource-based view (RBV). According to TCE, firms adopt a variety of relationships with each other in order to lower transaction costs associated with a purely transaction-based arrangement whereby relationships are based on market contracts (Coase, 1937; Williamson, 1975, 1985). RBV is based on the management of resources within the firm (Barney, 1991; Wernerfelt, 1984) and increasingly, across all actors in a supply chain (Dyer and Singh, 1998; Lavie, 2006; Peters et al., 2011; Schmoltzi and Wallenburg, 2011). Following an RBV approach, more partners in the cooperation agreement provides more resources from which to benefit, whereas according to TCE, communication and coordination become more complex as the number of firms increases (Schmoltzi and Wallenburg, 2011). Both of these approaches can help understand why particular governance forms are adopted.

In this paper, however, the interest is exploratory, to identify and classify different kinds of contracts and how they are used as a governance form to manage these transactions and resources. Therefore the theoretical approach has been drawn from governance analysis which is itself a large area of research.

Governance can be defined as a process of distributing authority and allocating resources, of managing relationships, behaviour or processes to achieve a desired outcome. Much governance literature is about process, asking questions about how power should be exercised, performance measured and outcomes regulated. This focus relates to the core of the difference between governance and government. It is not necessarily about the location of official responsibility but how a process is governed and an outcome achieved. In the field of (non-freight) transport, governance and institutional approaches have been applied predominately to transport provision and its regulation by government organisations (Curtis and Lowe, 2012; Geerlings and Stead, 2003; Gifford and Stalebrink, 2002; Legacy et al., 2012; Marsden and Rye, 2010; Pemberton, 2000; Stough and Rietveld, 1997).

\subsection{Port governance}

Port governance has been treated comprehensively in the literature. As major engines for driving economies, control of ports is a significant lever for governments to manage trade and its resultant economic benefits. Over recent decades, a general trend has been observed for port management to move from the public to the private sector. Numerous studies have examined different models of port governance (e.g., Baird, 2000, 2002; Baltazar and Brooks, 2001; Brooks, 2004; Brooks and Cullinane, 2007; Brooks and Pallis, 2008; Cullinane and Song, 2002; Everett and Robinson, 1998; Ferrari and Musso, 2011; Hoffman, 2001; Notteboom, 2006; Notteboom et al., 2013; Pallis and Syriopoulos, 2007; Verhoeven and Vanoutrive, 2012). The World Bank (2001, 2007) identified four models: the public service port, the private port, the tool port (a mixed model where private sector operators perform some of the operations but under the direction of public sector managers) and the landlord port (the public sector retains ownership while the terminal management and operations are leased to private sector operators). While the landlord model has become increasingly common across the globe and indeed 
encouraged by the World Bank and others, implementation of port devolution policies has been observed to vary according to local conditions (e.g., Baird, 2002; Ng and Pallis, 2010; Wang and Slack, 2004; Wang et al., 2004).

Advantages of greater private sector involvement in ports include increased efficiency and reduced cost to the public sector, while negative impacts include the loss or increased ambiguity of state control as well as the difficulties and risks involved in managing the tender process and subsequent monitoring (Baird, 2002). However, it has been found that governance decisions are not always related to port performance (Brooks and Pallis, 2008).

Bichou and Gray (2005) asserted that simple taxonomies are difficult because of the diversity of port functions [see also Beresford et al. (2004) and Sánchez and Wilmsmeier (2010)] and suggested that three elements are generally included: the role of public and private actors, the governance model and the scope of facilities, assets and services. This approach will underpin the current paper's attempt to expand simple terminal governance models with a focus on the responsibilities of key actors and how they are specified in contracts between them.

\subsection{Intermodal terminal governance}

Despite an extensive literature on the development and operation of intermodal terminals, governance has rarely been addressed directly, although it has been touched upon as part of other discussions. Lessons from governance analysis in the port sector have rarely been applied to intermodal terminals, regardless of the many similarities between the two settings $^{2}$. This is partly because inland freight nodes tend to be smaller concerns than ports, with simpler governance structures and less government involvement. While landlord models are in evidence, government involvement is more likely in the start-up phase using public money to attract a private operator into the market, after which it is assumed that the site will be run by private operators with no further government involvement (Monios, 2013). However, Bergqvist et al. (2010) showed that sites developed without direct involvement of an operator have been found to have higher risks of optimism bias. This is because terminal volume is linked to traffic flows; therefore the terminal operator requires a close relationship if not some level of integration with the rail operator to guarantee usage. The potential success of intermodal transport services relies on the logistics model of the clients and the relations with transport actors such as rail operators and port terminal operators. This is why the business model of the operational terminal must be linked with the initial decision to fund a terminal development.

Monios $(2013,2014)$ applied governance theory to the relationship between intermodal terminals and logistics platforms, developing a four-level conceptual framework:

1 the developer of the intermodal terminal and/or logistics platform

2 the operator of the intermodal terminal and/or logistics platform

3 internal operation model (relation between intermodal terminal and logistics platform)

4 external operation model (relation with clients and others). 
The fourth level of the typology was divided into three sections: relation between logistics platform and site tenants, relation between intermodal terminal and rail service providers and the relation between either the intermodal terminal or the logistics platform and ports. This paper will expand the second section in greater detail, in order to examine how the contract between the terminal operator and the rail service provider(s) affects the ability of the terminal operator to achieve not only their own goals of economic profitability, but more importantly the goals of the backers of the terminal (e.g., public sector planners and funders, rail authorities and/or regulators).

For example, government funders want to achieve modal shift by removing barriers to rail freight such as upfront costs, sunk costs and availability of suitable terminal locations, rail authorities want to provide sufficient capacity and quality of infrastructure for freight operators, rail regulators want to ensure fair competition and open access to infrastructure and terminals. But it is not clear that appropriate measures are enshrined in contracts in order to achieve these goals. Operators will only enter the market and provide services if they believe they can operate profitably, but government agencies must decide how to incentivise this market entry without granting monopoly power to an operator that would inhibit fair competition with other operators. There is no point exchanging the previous public monopoly with a new private monopoly.

Brooks and Cullinane (2007) analysed port governance models in terms of the key functions, resources and responsibilities of infrastructure owners, operators and regulators. This model can be adapted for analysis of governance models at intermodal terminals, identifying the key relationships that require contractual specification, which will then be analysed in the empirical section. Brooks and Cullinane (2007) also suggest that assigning clear roles for all actors (e.g., regulator, landlord, operator) is not always possible, due to the overlap and unclear boundaries between responsibilities. In order to identify these responsibilities, Table 1 sets out the key functions and actors in intermodal operations, expanded from a similar matrix developed by Baltazar and Brooks (2001) for analysis of port governance.

The table shows that some key areas of interest are shared between more than one actor, revealing that how these relationships are specified in contracts is a potential risk in achieving successful operations. Brooks and Cullinane (2007, p.412) state that "What is missing is the determination of whether highly prescriptive or loosely guided approaches are more effective in generating strong performance”. The public backers of a terminal want to incentivise this good performance, but how should the individual shared responsibilities be specified in order to achieve this?

Finally, Brooks and Cullinane (2007, p.433) assert that "ports do not appear to match methods of governing this activity with primary purpose, contrary to the principles proposed by the strategic management literature". If this is the case in ports which have a much more sophisticated and historical experience of devolution, privatisation and corporatisation, how much more likely is it for intermodal terminals where private operation is a relatively new area and governments are still attempting to find the best way of regulating them to achieve goals for all stakeholders? The research question for this paper is thus: how do the various contracts enable or constrain these goals? 
Table 1 Key functions and actors in intermodal operations

\begin{tabular}{|c|c|c|c|c|c|c|}
\hline Function & $\begin{array}{c}\text { Govt } \\
\text { dept/ } \\
\text { authority }\end{array}$ & $\begin{array}{l}\text { Infrastructure } \\
\text { regulator }\end{array}$ & $\begin{array}{c}\text { Infrastructure } \\
\text { (network) } \\
\text { owner }\end{array}$ & $\begin{array}{c}\text { Infrastructure } \\
\text { (terminal) } \\
\text { owner }\end{array}$ & $\begin{array}{l}\text { Terminal } \\
\text { operator }\end{array}$ & $\begin{array}{c}\text { Rail } \\
\text { operator }\end{array}$ \\
\hline Licensing/safety & & $\mathrm{X}$ & & & & \\
\hline $\begin{array}{l}\text { Emergency } \\
\text { services }\end{array}$ & & & $\mathrm{X}$ & & $\mathrm{X}$ & \\
\hline $\begin{array}{l}\text { Protection of } \\
\text { public interest }\end{array}$ & $\mathrm{X}$ & $\mathrm{X}$ & If public & If public & & \\
\hline $\begin{array}{l}\text { Setting policy } \\
\text { goals }\end{array}$ & $\mathrm{X}$ & & & & & \\
\hline Maintenance & & & $\mathrm{X}$ & $\mathrm{X}$ & $\mathrm{X}$ & \\
\hline $\begin{array}{l}\text { Marketing and } \\
\text { service } \\
\text { development }\end{array}$ & & & $\mathrm{X}$ & $\mathrm{X}$ & $\mathrm{X}$ & $\mathrm{X}$ \\
\hline $\begin{array}{l}\text { Land } \\
\text { acquisition and } \\
\text { disposal }\end{array}$ & & & $\mathrm{X}$ & $\mathrm{X}$ & & \\
\hline $\begin{array}{l}\text { Infrastructure } \\
\text { investment }\end{array}$ & & & $\mathrm{X}$ & $\mathrm{X}$ & $\mathrm{X}$ & \\
\hline $\begin{array}{l}\text { Equipment } \\
\text { investment }\end{array}$ & & & & $\mathrm{X}$ & $\mathrm{X}$ & \\
\hline Security & & & & & $\mathrm{X}$ & \\
\hline Cargo handling & & & & & $\mathrm{X}$ & \\
\hline $\begin{array}{l}\text { Transport } \\
\text { services } \\
\text { (mainline) }\end{array}$ & & & & & & $\mathrm{X}$ \\
\hline $\begin{array}{l}\text { Transport } \\
\text { services } \\
\text { (shunting within } \\
\text { the terminal) }\end{array}$ & & & & & $\mathrm{X}$ & \\
\hline
\end{tabular}

\section{The national context of intermodal terminal governance}

In this section the national context of intermodal terminal governance is explored based on the situations in Sweden and the UK.

When British Rail assets were privatised in the $1990 \mathrm{~s}^{3}$, the network infrastructure passed to newly-created company Railtrack (now Network Rail) ${ }^{4}$. Ownership of all British Rail's 12 container terminals went to the intermodal service operator Freightliner, which was privatised through a management buyout. As this operator was making a loss pre-privatisation, the buyout was incentivised via a track access grant of $£ 75 \mathrm{~m}$ (Fowkes and Nash, 2004). Private container terminals connected to the public network already existed at that time and new ones have been developed since, now operated by a diverse group such as rail operators (e.g., Freightliner, DB Schenker, DRS, First GBRf), 3PLs (e.g., WH Malcolm, Stobart, JG Russell), port operators (e.g., ABP) and others (Monios, 2012). Most of the sites are owner-operated, whereas some are leased from private sector 
companies such as real estate developers and a small number are leased from public sector entities such as municipalities and a few from Network Rail.

At privatisation, around $85 \%$ of UK rail freight was non-unitised general freight (mostly bulk) and the vast majority of freight handling sites were transferred to Railtrack/Network Rail. These sites were then leased to private operators, some on commercial rents but mostly on token or 'peppercorn' rents. The majority of these leases were for 125 years, with few requirements of the operators other than that the sites must remain open access and if they are not being used then they will return to the infrastructure owner. The majority of these sites were leased to the constituent companies that then formed EWS and were since acquired by DB Schenker. Ninty-two sites remained in the property of Railtrack, listed on a strategic freight site list that meant they could not be sold on for other use and must remain available for rail use. This list is reviewed regularly and sites may be taken off this list if it is felt that there is no realistic possibility of them being used again, in which case they can be sold for other purposes (ORR, 2011). As it is these general/bulk freight terminals rather than container terminals that are leased from the public sector to private operators, these are the UK contractual models that will be used for analysis in this paper.

If a terminal owner or operator wants to connect a site to the network (either reconnecting a disused terminal or a brand new connection for a new development), they must pay for all works including within the terminal boundary, the new connecting track and the switches and other work on the mainline. An agreement will be drawn up with Network Rail agreeing the annual maintenance costs of that section of track. There is a general scheme for freight infrastructure funding (FFG - recently scrapped in England and Wales but retained in Scotland) which can be used for any works on a terminal (e.g., new cranes, additional tracks, upgraded hard standing and also including the new mainline connection). This funding is to encourage modal shift from road to rail and is based on the operator identifying a stream of traffic that will shift to using the site if the work is carried out. However, there is no mechanism for taking this money back if the flow disappears, as long as the operator shows that it was not their fault.

The Swedish terminal network can be said to have evolved in stages ${ }^{5}$. The first stage was fairly intense development when the state-owned rail operator SJ built some 40 terminals to facilitate the start of intermodal traffic (Bergqvist et al., 2010). The terminal network was rationalised during the 1980s and 1990s and decreased to about 15 terminals. One explanation for the reduction of number of terminals was the increased focus on direct block trains, while the smaller terminals did not have a sufficient customer base to justify a full block train. New operators also settled into the market and the potential for cross-subsidisation between lines decreased. State profitability requirements of rail operations were also tightened during this period.

During the 1990s new terminals started to be developed again as a response to the deregulation of the railway market and the entrance of new rail operators. One of the reasons for the development was that the new rail operators had difficulty getting access to existing terminals since they were controlled by the main rail operator and not open access. The focus of the new operators was primarily on direct container shuttle trains to and from the port of Gothenburg. Examples of these are Eskilstuna, Nässjö, Insjön, Falköping, Hallsberg, Åmal and Ahus (c.f., Bergqvist and Flodén, 2010). In some cases ports also developed intermodal terminals.

The Swedish government has had a somewhat passive role in the development of intermodal terminals in the past. They have been more focused on ownership issues 
related to the state-owned rail operator, infrastructure development and the deregulation process. A few government-initiated investigations have been made focusing on the terminal network with the purpose of identifying critical terminals with special national interest from a transport system perspective. The purpose is to ensure that the Swedish Transport Administration considers these carefully in their overall planning and investment strategies for connecting infrastructure.

In both the UK and Swedish cases similar goals related to terminal development can be identified. From a public and landlord perspective, modal shift and sustainability remain the top priority, as well as congestion reduction, increasing employment and the competitiveness of local and regional businesses (c.f., Bergqvist, 2007; Bergqvist et al., 2010; Haywood, 2002; Woodburn, 2008).

Based on the situations in the UK and Sweden, a conceptual framework has been developed to illustrate the contractual context of intermodal terminal governance (Figure 1).

Figure 1 Conceptual framework of intermodal terminal governance and contracts

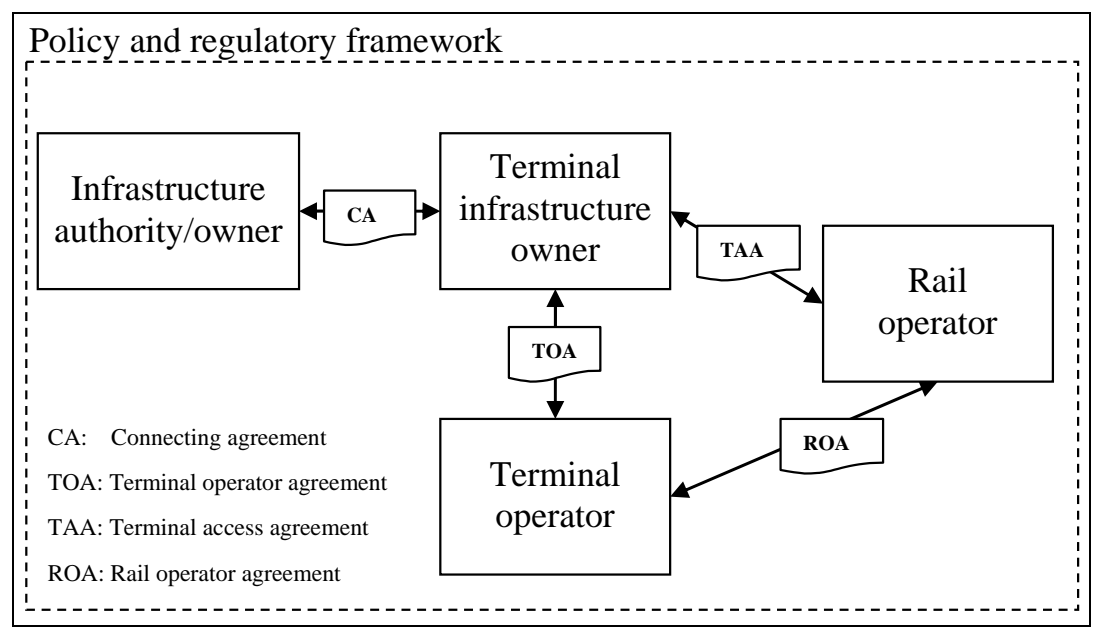

Figure 1 classifies the contractual agreements between the key stakeholders. Wiegmans et al. (1999) used Porter's (1980) five forces model to discuss relations between these stakeholders but empirical analysis of how such power relations operate in practice is rare. This analysis will be the focus of the empirical section to follow.

\section{Empirical data}

\subsection{Methodology}

The choice of a case study research approach was based on the ambition to analyse the dynamics of the phenomenon from a 'why' and 'how' perspective (c.f., Eisenhardt, 1989; Hilmola et al., 2005; Silverman, 2001; Yin, 1994). Case studies are particularly useful for exploratory research. The cases selected are Sweden and the UK, based on the rationale that these are two of the earliest countries in Europe to liberalise their rail freight networks and vertically separate infrastructure and services. 
For this paper, the contracts analysed in Sweden are mostly container and mixed container/bulk intermodal terminals, whereas in the UK they are general freight and bulk terminals. This is because in the UK container terminals are for the most part privately owned (see above), whereas general freight terminals are owned by the public sector and leased to private operators, thus providing a suitable axis of comparison of leasing models. The focus of this study is not the nature of shipment (bulk or containers) but the contractual agreements and context.

Some difference in relationships can be observed between Sweden and the UK, in that the terminal owner in the UK bulk market analysed in this paper is mostly the same as the infrastructure owner; it is primarily the UK container terminal market where the terminal owner will be different from the infrastructure owner. However, the same issues are addressed in the contracts, regardless of the precise relation of the actors, therefore the classification in Figure 1 allows both national contexts to be analysed.

Data availability in this field can be difficult due to commercial sensitivity which may also explain the paucity of research on this topic. It is, therefore, not appropriate to conduct quantitative analysis of contracts because strict frequency counts of certain contract clauses, for instance, could be misleading, especially with a small sample. The paper is therefore limited to an exploratory approach. The analysis proceeds inductively from a review of terminal contracts (identifying similarities, differences and uncertainties) to interviews with stakeholders (terminal owners, terminal operators, rail operators and public sector actors) to gather more insight on these issues. This process of analysis then leads to an identification of relevant issues in the contractual processes that will then be linked back to the key functions classified in the literature review. The goal is not to enumerate statistical frequencies of contract types but to explore the governance relationships and how they can be constrained or enabled by contract design, which has clear implications for policy makers.

A selection of agreements were analysed and issues relevant to the key functions identified in table 1 were drawn out and are listed below. The description is structured in accordance with the agreements specified in the conceptual framework illustrated in Figure 1.

\subsection{Connecting agreement (CA)}

This agreement regulates the framework and conditions for connecting the terminal with the rail network. The main conditions specified in the agreements are usually:

- $\quad$ physical boundaries

- $\quad$ time restrictions of the contract

- conditions for operations and maintenance across boundaries

- $\quad$ accessibility of road, facilities and installations

- demands and routines for documentation

- condition for transfer of contract in case of change of ownership of the terminal.

Overall, the agreement is very often focused on technical issues related to infrastructure and its boundaries in order to establish responsibility of specific parts of the infrastructure. 


\subsection{Terminal operator agreement (TOA)}

The terminal operator agreements (TOAs) have some obvious similarities with the CA but are generally much more comprehensive in their discussion of conditions for commercial operations. In this regard, it is important to emphasise that in the UK case of general freight terminals discussed in this paper (as opposed to UK container terminals), the terminal infrastructure owner and the infrastructure authority is generally the same organisation. The main issues generally addressed in this agreement are:

- physical boundaries

- fees and rent

- time restrictions (length of contract, possible extension)

- $\quad$ open access

- marketing and branding, resources

- options, e.g., first option to adjacent warehouses

- enough resources (financial competence to operate and develop the terminal)

- follow up (financially separated)

- facilitate hand-over

- follow general laws and regulations

- responsibilities for maintenance

- permission process for contract transfer

- damage regulation of infrastructure

- statistics and documentation of handled goods volumes, wagons, trains, etc.

The agreements often contain several conditions but most of them have difficulty defining key concepts and terms such as the process for hand-over, principles and conditions for infrastructure investments by the terminal operator and variable fees connected to different segments and services (e.g., fee per handled container, trailer, swap-body, storage of load units, etc.). Some agreements clearly define the price that the terminal operator can charge while others only focus on determining the fee or rent in the relationship between infrastructure authority/owner and terminal infrastructure owner. Another aspect often missing is the principles and process for capacity planning and the principles for assigning capacity to rail operators.

\subsection{Terminal access agreement (TAA)}

The agreement between the terminal owner and the rail operator usually focuses on:

- deadlines and routines for requesting capacity

- restrictions that they follow general and specific laws and regulations for that terminal 
- $\quad$ specifications for rail operator statistics and documentation of wagons and trains.

The documentation aspect is often related to invoicing of variable fees from the terminal infrastructure owner to the terminal operator. In Sweden the agreements usually do not involve the terminal operator as a contract party, whereas in the UK the reverse is the case, as it is the terminal operator who makes the agreement with the rail operator, therefore in that case the TAA and the ROA are the same document.

\subsection{Rail operator agreement (ROA)}

This agreement focuses on the commercial conditions for using the terminal and its services combined with conditions for capacity and the process for applying for capacity. The commercial conditions can look very different depending on the rail operator and the services offered and demanded and the length of the contract is usually about one to two years.

\section{Analysis of intermodal terminal governance}

\subsection{Summary of findings}

From analysing different types of agreements between different actors and through interviews with stakeholders a number of critical aspects related to stakeholder agreements have been identified. These are summarised in Table 2. The identified aspects for discussion can mainly be characterised as potential risks that the agreements and the underlying goals and incentives agreed upon become less effective.

Table 2 Comparing intermodal terminal governance in Sweden and the UK

\begin{tabular}{lcc}
\hline & Sweden & UK \\
\hline Rail market analysed & Container and general & General/bulk \\
Year of deregulation & 1996 & 1994 \\
Infrastructure ownership & Public & $\begin{array}{c}\text { Public (nominally-private but only } \\
\text { shareholder is the government) } \\
\text { Terminal ownership }\end{array}$ \\
Terminal operation & Public & Mostly public but some private \\
Open user & Mixed & Private \\
Vertical integration & Yes & Yes (for public sites only) \\
Contract length & Rare & Common \\
Maintenance & Short & Very long \\
Setter of terminal fees & Public & Private \\
Decider of handover & Public/private & Private \\
\hline
\end{tabular}

\subsection{Time-perspectives}

Divergent time-perspectives between the agreements constitute a risk that changes to incentives, etc. in an agreement cannot be effectively transferred to the interrelated 
agreements without a significant time lag. In Sweden, there is a tendency to sign rather short agreements, particularly for operations; TOAs are often shorter than five years. In the UK, leases are very long, typically 125 years and they can only be transferred either voluntarily by the operator, or else forced (what is called 'alienated') by the infrastructure owner. This is not a straightforward process and can be blocked by the timetabling of 'ghost' trains or tabling spot bids (ORR, 2011). In combination with requirements that the terminal operator needs to own and manage assets necessary for terminal operations, there is a built-in conflict in Sweden between short-term contracts and long-term investments in e.g., handling equipment. This divergence in time perspectives contributes to a lack of incentives for long-term investment and instead increases the likelihood of requiring short-term and more expensive solutions, such as short-term leasing of equipment (e.g., mobile cranes/reach-stackers). Yet in the UK, if a site is forcibly transferred to another operator, there remains the danger that an operator could lose their investment.

\subsection{Hand-over}

Principles for effective and efficient hand-over between terminal operators are another identified shortcoming in many of the studied TOAs. There are often sections stating that the current terminal operator should be helpful in contributing to a frictionless change of operators. However, few agreements define exactly how and the consequences if the terminal infrastructure owner believes the current terminal operator have not been sufficiently helpful. Indeed, the contract often does not define if the new terminal operator should have the opportunity to purchase equipment that the current operator possesses and uses for its terminal operations. Several terminal infrastructure owners in Sweden identified this as a problem when changing terminal operators and in some cases the consequences have been dramatic with terminal operations being offline for periods of time.

A further complication is when public backers develop a terminal that then runs at a loss and they would like to sell it off (often at a token price) to the private sector. This means that, not only is the public actor relinquishing control of the site but that the large investment will not be recouped and may need to be made again in future. This was the case with one of the municipality-owned Swedish terminals and represents the danger of not linking the initial funding decision to a coherent business model for site and service operation.

The handover issue is also relevant in the UK. In theory, if a site operator loses all its traffic to another operator, that operator can then take over lease of the site. But this makes it very difficult for a new operator to bid for traffic with the proviso that they have to take over the site; this uncertainty makes the new bid very unreliable and risky for both operator and potential customer. UK rail operators gave examples of both positive and negative transfers through the alienation process, but in the worst cases claims were made that potential business had been lost because site transfer could not be effected quickly enough to begin handling the new traffic.

A clearly defined principle that states key equipment that the new operator is entitled to take over and the associated principle for valuing that equipment would help overcoming this problem and risk. This would also reduce the inherent cost of changing terminal operator. 


\subsection{Fees and rent}

This is another complicated aspect where in Sweden there are great differences between different terminals and agreements. Some apply rents and fixed charges while others apply variable fees based on handled volumes or a combination of both. However, many terminal infrastructure owners described problems in forecasting different scenarios and situations beforehand and it is not unusual that the terminal operator attracts goods flows and goods types that are not clearly defined in the TOA. In those cases, the argument from the infrastructure owner is that this should be regulated through a separate agreement or the current agreement should be revised in line with the new circumstances. The terminal operator of course argues that, since this is an undefined segment developed by the terminal operator, it falls outside the scope of the current agreement and there is no justification for the terminal infrastructure owner to claim fees for this segment.

Several stakeholders have experienced this problem related to segments that were not anticipated and defined in the original TOA. Examples of such segments are handling and storage of cars, macadam or material for rail infrastructure construction. Some terminal infrastructure owners have regulated this by defining the goods segments and the corresponding fees in the TOA and in case there is a request for handling other types of goods, a separate agreement must be made, defining the conditions for this operation and segment. In some cases, this approach might be difficult when the time available for negotiating a complementary agreement is very limited until operations are planned to start. Overall, the level of fees and rent are at very low levels and rarely even cover the cost of maintenance and even less so the investment costs.

In the UK, rent of bulk terminals is a token 'peppercorn' rent. The operators are then free to do whatever they like with the terminal as long as the terminal remains in use and remains open access. If either of these situations change, then the terminal will go back to Network Rail who can then lease it to a new operator if any is interested. Such conditions are obviously very attractive to operators, who can set their own handling fees according to market forces. There is thus clear evidence suggesting that terminal operations in both countries are subsidised by the terminal infrastructure owner.

\subsection{Open access}

In most terminal infrastructure agreements and TOA s there are paragraphs emphasising the importance of open access. However, in the Swedish contracts, one single definition of the term cannot be found nor a description of how a failure to meet this condition would be determined or such accusations investigated.

The ORR (rail regulator in the UK) has been investigating whether some sites are really open access and if anti-competitive behaviour is in evidence and some sites may be taken back into public management (this includes both actual operating sites and so-called 'ransom strips' which are sections of marshalling/connecting track that a train must pass through to access a site) (ORR, 2011; Network Rail, 2012). All leased terminals must accept traffic from competitors unless the terminal is operating at full capacity, but it is not easy to specify exactly how capacity can be proven and the quality of service that must be provided to a competitor. A company can obey the letter of the law while still gaining undue competitive advantage. 
In theory, the failure to meet this condition would mean a cancellation of the contract, but the lack of definition and a clear process for investigating such circumstances is probably the reason why no stakeholders have experienced such a situation.

\subsection{Vertical integration}

Vertical integration between terminal operation and rail service operation is common in the UK since the majority of leased sites are operated by rail operators (in fact, the majority are operated by one firm: DB Schenker). Even the principle of alienation (where a terminal can be transferred to another owner if their services stop and someone else has services to that site) is based on which operator runs services.

An obvious comparison is with the USA where the rail industry is vertically integrated, from the track to the terminal to the services. Even in European countries, with vertical separation between track infrastructure and services, many service operators also operate terminals. Sweden is thus an unusual case where terminal operation is mostly by specialist terminal operators handling trains from other companies. This reduces issues such as managing alienation of a lease (as in the UK) but it means that terminal operations are less aligned with service requirements, as well as introducing transaction costs between the two companies as well as potential disagreements over pricing.

\subsection{Maintenance}

In Sweden, all agreements being signed between traffic authority, terminal infrastructure owner and/or terminal operator have clearly defined the physical boundaries of the infrastructure and the responsibilities related to maintenance and capacity planning. There are, however, rarely formulations related to the opportunity of collaborative efforts concerning tasks such as maintenance, snow clearance, etc., leaving considerable uncertainty over the potential for future unplanned costs arising. In the UK, this problem is resolved as everything within the site boundary is the responsibility of the terminal operator, while everything outside is the responsibility of the infrastructure owner, with a contract establishing the annual maintenance fee for those parts of the public way relating to the private terminal operator (e.g., switches, connecting tracks).

\section{Conclusions}

The port governance literature analysed in Section 2 demonstrated that the landlord model is a common governance structure to blend public and private motivations and outcomes. In the Swedish context, terminal infrastructure owners, usually a public actor, would prefer to play the landlord role but, due to their contracts with industry actors, continuously find themselves involved in daily operational and commercial situations. From a contractual agreements perspective, this is not surprising; given the fact that a lot of responsibilities and authority (e.g., snow clearance, traffic management) are linked directly back to the terminal infrastructure owner. This problem is amplified by issues such as divergence of time perspectives and unclearly defined incentives and principles of terminal operator hand-over. These issues are relevant not only to the individual cases but also reduce the efficiency of the intermodal system as a whole; for instance, a rail operator will be uncertain how much to charge its customers to recover its costs if it is 
not clear on fees or requirements on using a particular terminal or if there is uncertainty over responsibility for safety or snow clearance.

In the UK, sites are given on such long leases (and on a token 'peppercorn' rent) that they are almost given away. But the infrastructure owner retains control and if the site is not being used then it can take the site back. In Sweden, there is no specification in the initial funding contract to prevent this, even if the terminal was financed entirely by the public sector (e.g., municipality and national rail authority). Yet UK contracts have less control over the operator because once a site is given for 125 years on almost no rent, the operator is free to operate or invest as they see fit, with no public control to incentivise behaviour.

Another key observation is the lack of exercised power by the transport authority in many cases. Through the traffic agreement with terminal infrastructure owners they have the opportunity and ability to define and ensure key principles such as e.g., open access and return of public investments in case of the terminal being sold in the future. Yet few observations have been made in Sweden where such principles have been defined in the agreement between the rail authority and terminal infrastructure owner. In the UK, the infrastructure owner also exerts little control on the terminal operation; the view appears to be that as long as the terminal is being used and it does not require management or funding from government then that is acceptable. Unless another operator challenges this situation with an accusation of anti-competitive behaviour or that the terminal is not in fact being used and they would like to take it over, then terminal operators can continue as they like.

The underlying trend in both markets is therefore that public actors do not exert significant influence, although in each country this is for different reasons. In Sweden they would actually prefer less direct involvement; they want a basic landlord form as long as they are able to specify some key conditions. However, due to the form of the contracts and the complex incentives involved, they keep getting drawn in to daily management and operational discussions. Yet some success is evident in the Swedish model; the evidence suggests that operators have been incentivised to enter the market and are developing terminals and increasing flows. The public actors want to step back if they can but find themselves unable to do so.

The question arises as to whether it is unrealistic to want to have an active private actor developing and operating successful terminals while thinking the public actor can make some investments and developments and then step back and retain only a landlord position. It may be that they have to remain rather involved through active PPP arrangements in order to monitor whether the terminal is achieving the goals for which it was funded. What is the best model for achieving this? In the UK, the current model of long leases with few conditions makes management simpler for the public actors, meaning that they do not have the daily operational difficulties and entanglements that the Swedish actors experience. The disadvantage is that private operators are then insufficiently incentivised to invest and expand; they can simply occupy old terminals, sweating old assets and requesting government funding through the modal shift grants system when they need upgrades. Similar criticisms have been made of the fully-privatised UK port model (Baird, 2013).

One difficulty underlining these trends (both the undesirably active role in Sweden and the overly inactive role in the UK) is that government actors (at all levels) do not have the knowledge to specify contracts. This results in all sorts of different contracts with divergent time periods and responsibilities with very few penalties for 
non-compliance, if it can even be identified and assessed. What is needed in Sweden is for government agencies to use industry expertise to draw up a generic contract that can be applied across the sector to increase standardisation and reduce divergent contracts with misaligned motivations and instruments for achieving them. Likewise in the UK, a standard contract form with increased stipulations could be utilised to incentivise more proactive developments by private operators that would reduce the risk of competitors complaining that they are not fulfilling the terms of said contracts. Intermodal transport developed as a mode due to increasing standardisation of equipment from container sizes to wagon types to cranes and handling techniques. Such standardisation must also be applied to contracts in order to facilitate successful intermodal transport. The research in this paper can be used in future research as a basis to develop a template applicable in other national contexts to compare how the same contractual features are managed in other cases, working towards a standard framework for analysis.

It was noted in the literature review that TCE and RBV have been used fruitfully in logistics research to analyse the management of relationships and resources. Now that this paper has identified and classified different kinds of contracts and how they are used as a governance form to manage these transactions and resources, future research could use TCE or RBV to explore these issues in greater depth. The particular roles of the actors identified in this research (terminal owners, terminal operators, rail operators and rail regulators) could be explored through an actor-centric analysis using either of these theoretical approaches. Such research could provide deeper understanding of how the interests of these actors tend to result in certain governance forms that may inhibit the achievement of policy goals. From a practical perspective, future research on such contracts could also explore additional desirable features, such as how the concessioning process should take place, standard requirements for tenderers and other allowances such as, for example, using overweight or longer trucks to bring containers to the terminal or subsidised rents for logistics platform tenants utilising a terminal.

\section{Acknowledgements}

Research for this paper was conducted with the financial support of the EU-funded Green Corridors project, financed through the ERDF Interreg IVB North Sea Region Programme, The Swedish Transport Administration and The Sustainable Transport Initiative financed through the Swedish Government. 


\section{References}

Alexandersson, G. and Rigas, K. (2013) 'Rail liberalisation in Sweden. Policy development in a European context', Research in Transportation Business \& Management, April, Vol. 6, pp.88-98.

Baird, A. (2002) 'Privatization trends at the world's top-100 container ports', Maritime Policy \& Management, Vol. 29, No. 3, pp.271-284.

Baird, A. (2013) 'Acquisition of UK ports by private equity funds', Research in Transportation Business \& Management, October, Vol. 8, pp.166-169.

Baird, A.J. (2000) 'Port privatisation: objectives, extent, process and the UK experience', International Journal of Maritime Economics, Vol. 2, No. 3, pp.177-194.

Baltazar, R. and Brooks, M.R. (2001) 'The governance of port devolution: a tale of two countries', Proceedings of the 9th World Conference on Transport Research, Seoul.

Barney, J. (1991) 'Firm resources and sustained competitive advantage', Journal of Management, Vol. 17, No. 1, pp.99-120.

Beresford, A., Pettit, S., Xu, Q. and Williams, S. (2012) 'A study of dry port development in China’, Maritime Economics \& Logistics, Vol. 14, No. 1, pp.73-98.

Beresford, A.K.C., Gardner, B.M., Pettit, S.J., Naniopoulos, A. and Wooldridge, C.F. (2004) 'The UNCTAD and WORKPORT models of port development: evolution or revolution?', Maritime Policy \& Management, Vol. 31, No. 2, pp.93-107.

Bergqvist, R. (2007) Studies in Regional Logistics - The Context of Public-Private Collaboration and Road-Rail Intermodality, Logistics and Transport Research Group, Department of Business Administration, BAS Publishing, Göteborg, Sweden.

Bergqvist, R. (2013) 'Hinterland transport in Sweden - the context of intermodal terminals and dryports', in Bergqvist, R., Wilmsmeier, G. and Cullinane, K. (Eds.): Dryports - A Global Perspective, Challenges and Developments in Serving Hinterlands, Ashgate Publishing Limited, Farnham, England.

Bergqvist, R. and Flodén, J. (2010) 'Intermodal road-rail transport in Sweden -on the path to sustainability', World Conference on Transport Research, 11-15 July 2010, Lisbon.

Bergqvist, R., Falkemark, G. and Woxenius, J. (2010) 'Establishing intermodal terminals', International Journal of World Review of Intermodal Transportation Research (WRITR), Vol. 3, No. 3, pp.285-302

Bichou, K. and Gray, R. (2005) 'A critical review of conventional terminology for classifying seaports', Transportation Research Part A: Policy and Practice, Vol. 39, No. 1, pp.75-92.

Brooks, M. and Pallis, A.A. (2008) 'Assessing port governance models: process and performance components’, Maritime Policy \& Management, Vol. 35, No. 4, pp.411-432.

Brooks, M.R. (2004) 'The governance structure of ports', Review of Network Economics, Vol. 3, No. 2, pp.168-183.

Brooks, M.R. and Cullinane, K. (2007) Devolution, Port Governance and Port Performance, Elsevier, London.

Caris, A., Macharis, C. and Janssens, G.K. (2008) 'Planning problems in intermodal freight transport: accomplishments and prospects', Transportation Planning \& Technology, Vol. 31, No. 3, pp.277-302.

Coase, R.H. (1937) 'The nature of the firm', Economica, Vol. 4, No. 16, pp.386-405.

Cullinane, K. and Song, D.W. (2002) 'Port privatisation policy and practice', Maritime Policy and Management, Vol. 22, No. 1, pp.55-75.

Curtis, C. and Lowe, N. (2012) Institutional Barriers to Sustainable Transport, Ashgate, Farnham, Surrey.

Dyer, J.H. and Singh, H. (1998) 'The relational view: cooperative strategy and sources of interorganizational competitive advantage', Academy of Management Review, Vol. 23, No. 4, pp.660-679. 
Eisenhardt, J. (1989) 'Building theories from case study research', Academy of Management Review, Vol. 14, No. 4, pp.532-550.

Everett, S. and Robinson, R. (1998) 'Port reform in Australia: issues in the ownership debate', Maritime Policy \& Management, Vol. 25, No. 1, pp.41-62.

Ferrari, C. and Musso, E. (2011) 'Italian ports: towards a new governance?', Maritime Policy \& Management, Vol. 38, No. 3, pp.335-346.

Flämig, H. and Hesse, M. (2011) 'Placing dryports. Port regionalization as a planning challenge the case of Hamburg, Germany and the Süderelbe', Research in Transportation Economics, Vol. 33, No. 1, pp.42-50.

Fowkes, A.S. and Nash, C.A. (2004) Rail Privatisation in Britain - Lessons for the Rail Freight Industry, ECMT Round Table 125, European Integration of Rail Freight Transport, Leeds, UK.

Geerlings, H. and Stead, D. (2003) 'The integration of land use planning, transport and environment in European policy and research', Transport Policy, Vol. 10, No. 4, pp.187-196.

Gifford, J.L. and Stalebrink, O.J. (2002) 'Remaking transportation organizations for the 21st century: consortia and the value of organizational learning', Transportation Research Part A, Vol. 36, No. 7, pp.645-657.

Haywood, R. (2002) 'Evaluation of the policies in British local transport plans with regard to the promotion of rail freight', Transport Reviews, Vol. 23, No. 4, pp.387-412.

Hesse, M. (2008) The City as a Terminal: The Urban Context of Logistics and Freight Transport, Ashgate, London.

Hilmola, O-P., Hejazi, A. and Ojala, L. (2005) 'Supply chain management research using case studies', International Journal of Integrated Supply Management, Vol. 1, No. 3, pp.294-311.

Hoffmann, J. (2001) 'Latin American ports: results and determinants of private sector participation’, International Journal of Maritime Economics, Vol. 3, No. 2, pp.221-241.

Lavie, D. (2006) 'The competitive advantage of interconnected firms: an extension of the resourcebased view', Academy of Management Review, Vol. 31, No. 3, pp.638-58.

Legacy, C., Curtis, A. and Sturup, S. (2012) 'Is there a good governance model for the delivery of contemporary transport policy and practice? An examination of Melbourne and Perth', Transport Policy, Vol. 19, No. 1, pp.8-16.

Liedtke, G. and Carillo Murillo, D.G. (2012) 'Assessment of policy strategies to develop intermodal services: the case of inland terminals in Germany', Transport Policy, November, Vol. 24, pp.168-178.

Marsden, G. and Rye, T. (2010) 'The governance of transport and climate change', Journal of Transport Geography, Vol. 18, No. 6, pp.669-678.

Monios, J. (2012) 'Retail logistics in the UK', Paper presented at International Conference on Logistics \& Sustainable Transport, Celje, Slovenia, June 2012.

Monios, J. (2013) Identifying Governance Relationships Between Intermodal Terminals and Logistics Platforms, TRI Working Paper.

Monios, J. (2014) Institutional Challenges to Intermodal Transport and Logistics, Ashgate, London.

Monios, J. and Wilmsmeier, G. (2012) 'Giving a direction to port regionalisation', Transportation Research Part A: Policy \& Practice, Vol. 46, No. 10, pp.1551-1561.

Nash, C. (2002) 'Regulatory reform in rail transport - the UK experience', Swedish Economic Policy Review, Vol. 9, No. 2, pp.257-286.

Network Rail (2012) Proposed Acquisition of DB Schenker (UK) Ltd/English Welsh \& Scottish Railway International Ltd Freight Sites: A Consultation, Network Rail, London.

Ng, A.K.Y. and Gujar, G.C. (2009) 'Government policies, efficiency and competitiveness: the case of dry ports in India’, Transport Policy, Vol. 16, No. 5, pp.232-239. 
Ng, A.K.Y. and Pallis, A.A. (2010) 'Port governance reforms in diversified institutional frameworks: generic solutions, implementation asymmetries', Environment \& Planning A, Vol. 42, No. 9, pp.2147-2167.

Notteboom, T. (2006) 'Concession agreements as port governance tools', Research in Transportation Economics, Vol. 17, pp.437-488.

Notteboom, T., de Langen, P. and Wouter, J. (2013) 'Institutional plasticity and path dependence in seaports: interactions between institutions, port governance reforms and port authority routines', Journal of Transport Geography, February, Vol. 27, pp.26-35.

ORR (2011) Rail Freight Sites: ORR Market Study, ORR, London.

Pallis, A.A. and Syriopoulos, T. (2007) 'Port governance models: financial evaluation of Greek port restructuring', Transport Policy, May, Vol. 14, pp.232-246.

Pemberton, S. (2000) 'Institutional governance, scale and transport policy - lessons from Tyne and Wear', Journal of Transport Geography, Vol. 8, No. 4, pp.295-308.

Peters, N.J., Hofstetter, J.S. and Hoffmann, V.H. (2011) 'Institutional entrepreneurship capabilities for interorganizational sustainable supply chain strategies’, The International Journal of Logistics Management, Vol. 22, No. 1, pp.52-86.

Porter, M. (1980) Competitive Strategy, The Free Press, New York.

Rodrigue, J-P., Comtois, S., Slack, B. (2013) The Geography of Transport Systems, 3rd edition, Routledge.

Rodrigue, J-P., Debrie, J., Fremont, A. and Gouvernal, E. (2010) 'Functions and actors of inland ports: European and North American dynamics’, Journal of Transport Geography, Vol. 18, No. 4, pp.519-529.

Roso, V. (2008) 'Factors influencing implementation of a dry port', International Journal of Physical Distribution \& Logistics Management, Vol. 38, No. 10, pp.782-798.

Sánchez, R. and Wilmsmeier, G. (2010) 'Contextual port development: a theoretical approach', in Coto-Millán, P., Pesquera, M. and Castanedo, J. (Eds.): Essays on Port Economics, pp.19-44, Springer, New York.

Schmoltzi, C. and Wallenburg, C.M. (2011) 'Horizontal cooperations between logistics service providers: motives, structure, performance', International Journal of Physical Distribution \& Logistics Management, Vol. 41, No. 6, pp.552-576.

Silverman, D. (2001) Interpreting Qualitative Data: Methods for Analysing Task, Text and Interaction, London, Sage.

Stough, R.R. and Rietveld, P. (1997) 'Institutional issues in transport systems', Journal of Transport Geography, Vol. 5, No. 3, pp.207-214.

Verhoeven, P. and Vanoutrive, T. (2012) 'A quantitative analysis of European port governance', Maritime Economics \& Logistics, Vol. 14, No. 2, pp.178-203.

Wang, J.J. and Slack, B. (2004) 'Regional governance of port development in China: a case study of Shanghai International Shipping Centre', Maritime Policy \& Management, Vol. 31, No. 4, pp.357-373.

Wang, J.J., Ng, A.K.Y. and Olivier, D. (2004) 'Port governance in China: a review of policies in an era of internationalizing port management practices', Transport Policy, Vol. 11, No. 3, pp.237-250.

Wernerfelt, B. (1984) 'A resource-based view of the firm', Strategic Management Journal, Vol. 5, No. 2, pp.171-180.

Wiegmans, B.W., Masurel, E. and Nijkamp, P. (1999) 'Intermodal freight terminals: an analysis of the terminal market', Transportation Planning \& Technology, Vol. 23, No. 2, pp.105-128.

Williamson, O.E. (1975) Markets and Hierarchies: Analysis and Antitrust Implications, The Free Press, New York.

Williamson, O.E. (1985) The Economic Institutions of Capitalism, The Free Press, New York.

Woodburn, A. (2008) 'Intermodal rail freight in Britain: a terminal problem?', Planning, Practice \& Research, Vol. 23, No. 3, pp.441-460. 
World Bank (2001) Port Reform Toolkit, World Bank, Washington DC.

World Bank (2007) Port Reform Toolkit, 2nd ed., World Bank, Washington DC.

Yin, R.K. (1994) Case Study Research, Designs and Methods, Sage, London.

\section{Notes}

1 Since 1991, EU directive 91/440 has required that all EU countries separate management of infrastructure from services. Even if the national company still operates both, full separation of management and transparent charging and accounting is required, in order to facilitate on-rail competition across a shared infrastructure.

2 Exceptions being Beresford et al. (2012), Monios (2013), Rodrigue et al. (2010), Rodrigue et al. (2013) - for more discussion see Monios (2014).

3 For a detailed account of the privatisation of the UK rail industry, see Nash (2002).

4 Railtrack was created as a private commercial company but it went bankrupt and infrastructure ownership was then repackaged under the ownership of Network Rail, a nominally-private company but owned solely by the government. Fowkes and Nash (2004) suggest that keeping the infrastructure publicly owned (as in Sweden) was better than the UK model where the infrastructure owner attempted to act as a commercial company.

5 For a detailed account of the liberalisation of the Swedish rail industry, see Alexandersson and Rigas (2013). 